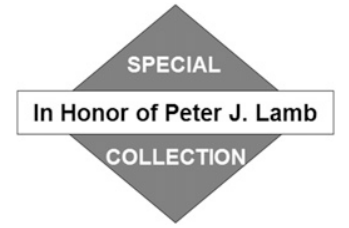

\title{
Droughts and Agriculture in the Semi-Arid Region of Maharashtra, Western India
}

\author{
RAHUL S. TODMAL \\ Department of Geography, Vidya Pratishthan's Arts, Science \& Commerce College, Baramati, Pune, India
}

(Manuscript received 11 December 2018, in final form 18 June 2019)

\begin{abstract}
In the prevailing climate change scenario, to cope with drought, it is necessary to understand the characteristics of meteorological droughts in water-scarce regions to formulate judicial plans for the utilization of water resources. The present investigation, therefore, endeavored to assess the intensity and frequency of droughts over the five semiarid river basins in Maharashtra during the past (1980-2013) and future (2015-50). The study was carried out with the application of standardized precipitation index (SPI) methodology. The agricultural and satellite [normalized difference vegetation index (NDVI)] data were analyzed to understand the effects of meteorological droughts. Although the study area experienced three severe rainfall droughts in 1985/86, 2002/03, and 2011/12, higher frequency of low-intensity droughts is observed, particularly after 2000. The estimation suggests occurrence of moderate, severe, and extreme droughts once in 6,28 , and 50 years, respectively. Among the selected basins, the Agrani, the Karha, and the Man are expected to experience intense droughts and hence require special attention in drought management. The study also highlights that El Niño events considerably retard the monsoon rainfall. However, the occurrence of the positive phase of the Indian Ocean dipole in the El Niño years reduces the intensity of droughts. As agricultural productivity and cropped areas heavily depend on the monsoon rainfall, the meteorological droughts result in agricultural droughts. Moreover, the future warming $\left(\right.$ by $\left.1.02^{\circ} \mathrm{C}\right)$ over the study area is very likely to exacerbate the meteorological droughts (estimated to occur in the 2030s) and increase the agricultural water demand, further adding to an already difficult water management challenge in the study basins.
\end{abstract}

\section{Introduction}

Drought is a major climatic hazard resulting from the deficiency of water falling below the expected amount for protracted period, which is a case of hydrological extreme. Among all the natural hazards, drought has maximum impact in terms of damage to society (Mishra and Singh 2010). Although the frequency, duration, and intensity of droughts vary in different climatic and hydrological regimes, it has been experienced in almost all the regions of the world (Hisdal and Tallaksen 2000). During the drought period, water scarcity affects all human activities in general and agricultural activities in particular, leading to reductions in agricultural production and productivity in the arid and semiarid regions (Das et al. 2003; Pandey et al. 2008).

To quantify various characteristics of drought, operational definitions are constructed in the form of drought indices (Smakhtin and Hughes 2004). As drought is a

Corresponding author: Rahul S. Todmal, todmalrahul@gmail.com relative phenomenon (Van Loon 2015), various regionwise indices and methods are being used for its quantification. The Palmer drought severity index (PDSI), developed by Palmer (1965), is a widely used drought index. It was constructed for topographically homogeneous regions and was based on the data on soil moisture, precipitation, temperature, and evapotranspiration (Palmer 1965; Maliva and Missimer 2012). Given the requirement of data on multiple weather parameters, the calculation of PDSI is quite complex (Maliva and Missimer 2012) and has been assessed, criticized, and modified for several reasons during the last 50 years. The standardized precipitation index (SPI), introduced by McKee et al. (1993), overcomes the limitations of the PDSI, as it is simple to calculate and requires minimum data. As the SPI has the advantage of applicability for all types of climatic regions, thereby allowing spatial comparison of drought, it has been extensively used to assess regional droughts in all parts of the world, particularly during the last two decades. Based on the same methodology, attempts have been made to develop the standardized runoff index 
(SRI) (Shukla and Wood 2008) and standardized water-level index (SWI) (Bhuiyan et al. 2006) to quantify the hydrological droughts.

In India, about $15.8 \%$ (50.8 Mha) of the geographical area is arid and nearly $37.6 \%$ (123.4 Mha) is characterized by semiarid climatic conditions (Ajai et al. 2009). Therefore, drought is one of the major disasters, as it affects the agrarian economy of the country. To understand the spatial and temporal characteristics of drought over all or some meteorological subdivisions in India, several scientific studies (Sinha Ray and Shewale 2001; Gore and Sinha Ray 2002; Shewale and Kumar 2005; TERI 2014; and many others) have been devoted to this work. Since it is a drought-prone state, identification and projection of drought in Maharashtra are the main focus of hydrological studies. Although it is an example of an industrialized state, more than $50 \%$ of the population depend on the agriculture and allied activities for their livelihood (Kalamkar 2011), which increases the vulnerability of drought disaster. Because of high annual variability, the semiarid region in the state frequently suffers from the water scarcity problem. Particularly, the Madhya Maharashtra and Marathwada Subdivisions (Chowdhury and Abhyankar 1984) are observed with higher drought frequency. Based on a Markov chain model, Khambete and Biswas (1984) have identified drought-prone zones in the state. The chronic drought-prone zone in Maharashtra (covering most of the present study area) registered the highest frequency of drought (Deosthali 2002). The drought studies carried out by Gore and Sinha Ray (2002) and Gore et al. (2010) emphasize the same fact. The occurrence of drought affects the production and productivity of sorghum and pearl millet crops in this region of the state (Gore and Sinha Ray 2002). With the application of remote sensing techniques, Messina (2013) has attempted to map the effects of 2003 drought conditions in the Krishna basin. It is reported that the drought and flood disasters in 2003 and 2005, respectively, have devoured more funds than the planned budget of the rural and agriculture sectors in Maharashtra State for 2002-07 (World Bank 2008). The recent drought experienced in 2012 has adversely affected the agrarian economy of Maharashtra (Udmale et al. 2014). The Intergovernmental Panel on Climate Change (IPCC 2013) has estimated an increase in frequency of drought over the semiarid regions of India (including the present study area). Moreover, the projected rise in temperature (by $1.5^{\circ}-3^{\circ} \mathrm{C}$ ) over Maharashtra is very likely to amplify drought intensity in the semiarid region, which may increase agrarian stress (TERI 2014).
On this background, the present study endeavors to evaluate the drought intensity and frequency over five semiarid river basins in Maharashtra. Additionally, with the use of projected data, future drought events are estimated. Understanding of the linkage between drought and El Niño events is another objective of this study. As the drought disaster adversely affects agriculture, an attempt has also been made to assess the connection of monsoon condition with agricultural productivity and cropped area. Additionally, the effect of drought on the agricultural cropped area is confirmed by remote sensing techniques.

\section{Study area}

About $83 \%$ of the land area of Maharashtra is characterized by semiarid climatic conditions (World Bank 2003; Kalamkar 2011). On account of the orographic effect, the leeward side of the Western Ghats receives a very scanty amount $(<700 \mathrm{~mm})$ of precipitation (Fig. 1a) (Gadgil 2002). Almost the entire Madhya Maharashtra Subdivision falls in this low rainfall zone (Fig. 1a). The monsoon precipitation over this subdivision is observed with higher coefficients of variation (24\%-57\%) (Guhathakurta and Saji 2013), which results in a $20 \%-30 \%$ probability of drought (Gadgil 2002; Gore et al. 2010). Several regionwide droughts of moderate to extreme intensity were experienced in Madhaya Maharashtra between 1871 and 2016 (Fig. 2), which have adversely affected the agricultural crops (Gore and Sinha Ray 2002).

\section{a. Selection of river basins}

For the present investigation, the Sina, Karha, Yerala, Agrani, and Man basins were selected, which cover about $24000 \mathrm{~km}^{2}$ (Fig. 1a) in area. These river basins from low-rainfall zone meet the following criteria:

- The river does not have its source in the high-rainfall zone of the Western Ghats but within the rain shadow zone.

- At least a part of the basin falls in the chronic to severe drought-prone zone, with annual rainfall of $<600 \mathrm{~mm}$ and annual water deficit of $>900 \mathrm{~mm}$.

- Adequately long ( $>20$ years) hydrological (rainfall, discharge and groundwater level) data are available.

Among the selected river basins, the Sina $\left(12365 \mathrm{~km}^{2}\right)$ and Karha $\left(1141 \mathrm{~km}^{2}\right)$ are the largest and smallest basins, respectively.

\section{b. Climate and agricultural setting}

The selected river basins drain part of Madhya Maharashtra Subdivision and experience a semiarid 

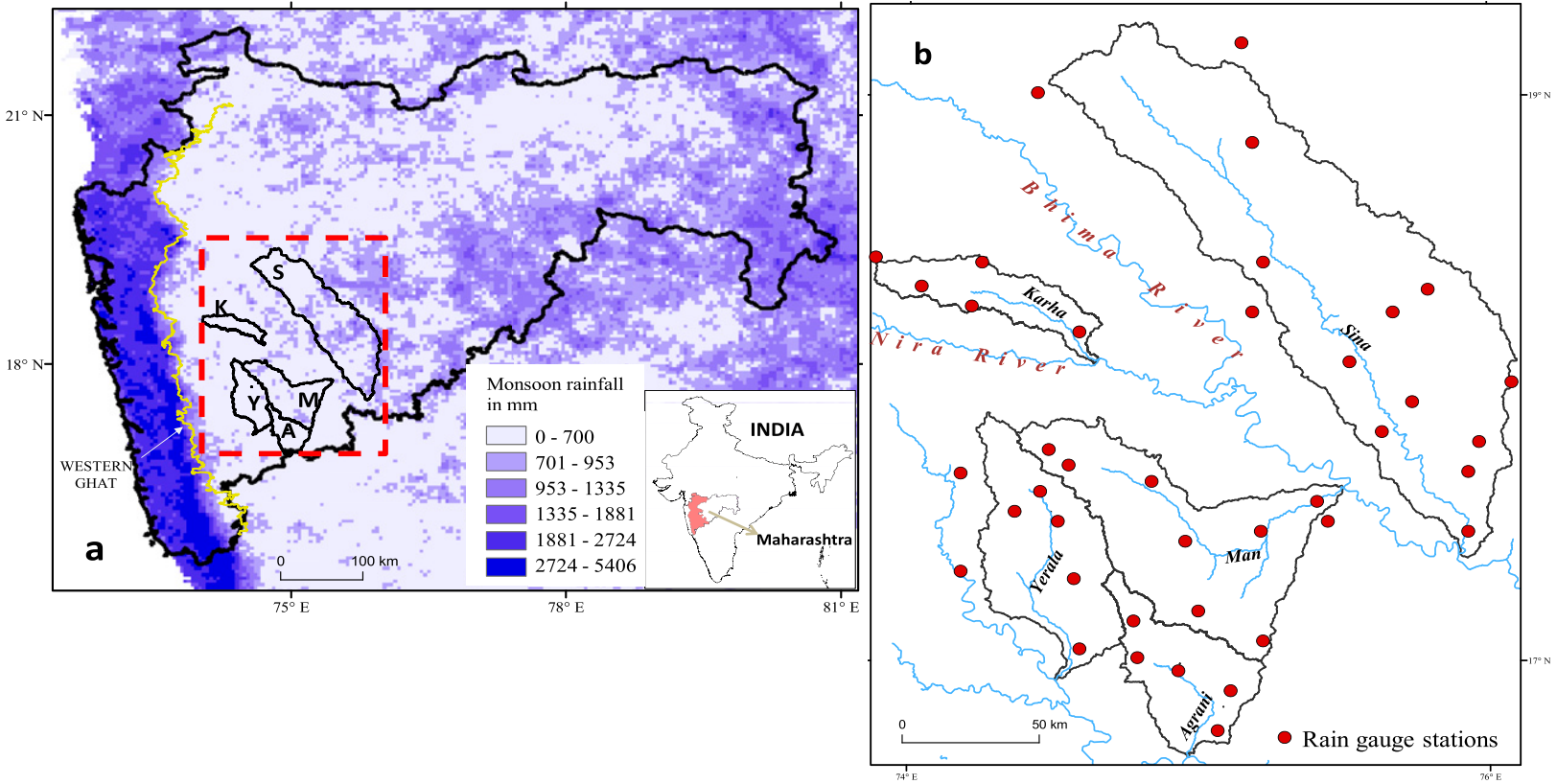

FIG. 1. (a) Location of the study basin and distribution of rainfall over the Maharashtra State. Rainfall classes are based on the natural breaks. The pink color in the inset map of India shows Madhya Maharashtra Subdivision. $\mathrm{K}=\mathrm{Karha}, \mathrm{Y}=\mathrm{Yerala}, \mathrm{M}=\mathrm{Man}$, A = Agrani, and S = Sina river basins. Projected rainfall and temperature data were collected for the area demarcated by the red dashed square. (b) Distribution of the selected rainfall stations over the study area. Source of TRMM data: http:// www.geog.ucsb.edu/ bodo/TRMM/.

tropical monsoon (Köppen classification Bsh) type of climate (IMD 2005). Being a part of the rain shadow zone of the Western Ghats, the selected basins receive annual precipitation between 500 and $750 \mathrm{~mm}$, about $90 \%$ of which falls during the five months (June-October) of the southwest monsoon season. Although these basins are the part of same climatic zone, they exhibit notable spatial variation in monsoon rainfall (Sina $584 \mathrm{~mm}$, Man $453 \mathrm{~mm}$, Agrani $313 \mathrm{~mm}$, Yerala $502 \mathrm{~mm}$, and
Karha $490 \mathrm{~mm}$ ). The mean daily temperature is generally above $22^{\circ} \mathrm{C}$, except during winter $\left(18^{\circ}-22^{\circ} \mathrm{C}\right)$. The mean maximum temperature varies between $30^{\circ}$ and $40^{\circ} \mathrm{C}$ from May to October, but is generally below $32^{\circ} \mathrm{C}$ in the remaining months of the year (IMD 2005). Given the high ambient temperatures throughout the year, the potential evapotranspiration (PET) tends to be high (between 1600 and $1800 \mathrm{~mm}$ ), which results in annual water deficiency of more than $900 \mathrm{~mm}$

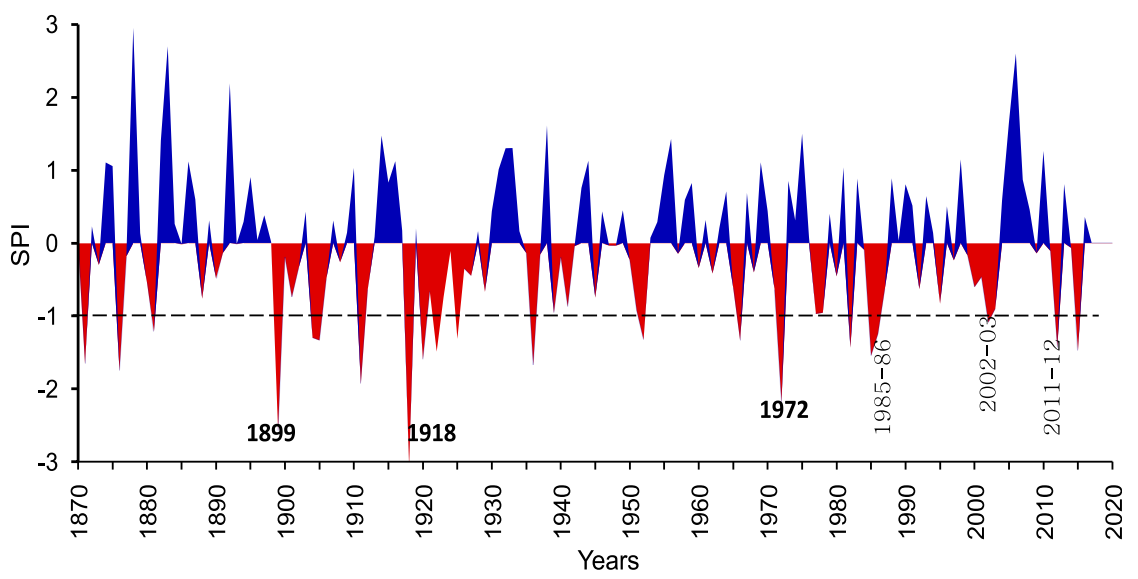

FIG. 2. Time series plot of SPI values for annual monsoon rainfall over the Madhya Maharashtra Subdivision. Basic data source: Indian Institute of Tropical Meteorology (IITM), Pune. 
(Dikshit 1983). By considering probability of drought occurrence, the study basins are the part of chronically drought-prone area (Khambete and Biswas 1984).

Agro-climatologically, the selected basins are part of the scarcity zone of Maharashtra, where agriculture is rain dependent (Kalamkar 2011). Therefore, the cultivation of short-duration and drought-tolerant crops (sorghum, pearl millet, gram pigeon pea) is the chief characteristic of the agriculture (Deosthali 2002; Kalamkar 2011). Sorghum and pearl millet are the dominant crops, which cover about $50 \%-60 \%$ of the cropped area. Because of their lower market value, the traditional crops in this region are being replaced by cash crops such as sugarcane, maize, and onion (World Bank 2008; Kalamkar 2011; Todmal and Kale 2016).

\section{Material and methods}

\section{a. Data collection and preparation}

As the present study is mainly focused on the meteorological droughts, daily monsoon rainfall data (June-October) of 40 well-distributed stations over the selected river basins were collected from the India Meteorological Department (IMD) and Hydrological Data Users Group (HDUG) for about three decades (1981-2013). The acquired rainfall data from the Agriculture Department of Maharashtra State (ADMS) were used to fill the missing rainfall records (about 5\%). The remaining $\sim 7 \%$ missing values were filled by adopting the linear regression approach. The Thiessen polygon method was used to calculate the average basin rainfall over each of the selected river basins.

One of the major objectives of this investigation was to understand the effect of meteorological droughts on the agriculture in the selected semiarid river basins. For this, the agricultural crop productivity and cropped area data of 37 talukas, which partially or completely fall in the selected river basins, were acquired from the ADMS for the period between 1980 and 2014. The missing records in the agricultural data (about 2\%) were estimated by averaging the succeeding and preceding year's values. To derive the average productivity of each crop in the study area (average for five basins), yearly average productivity values were calculated for the entire study area (average of 37 taluka-wise values). There is a good relation between summer monsoon rainfall and NDVI values during winter (October-December) or the postmonsoon season over the Indian region (Revadekar et al. 2012) as well as in the Upper Krishna basin (Dodamani et al. 2015). The postmonsoon cropped area, which has considerable share of greenery cover in the study area (Gumma et al. 2011), is heavily dependent on the rainfall received during the rainy season. Therefore, to confirm the findings on cropped area vis-à-vis meteorological droughts in the selected river basins, the present study has attempted to identify the pattern and range of NDVI values (for vegetation cover including the cultivated cropped area) over the study area for the drought (2002) and surplus (1998) monsoon years. The vegetation cover and agriculture during the postmonsoon period represent monsoon condition in that year. For this, the Landsat-5 TM freely available images $(30 \mathrm{~m})$ were downloaded for the postmonsoon months (November and December). Additionally, the difference between class-wise NDVI values in wet and drought years was verified with the use of the Student's $t$ test. To understand the connection between observed droughts over the present study area (basins) with the Southern Oscillation index (SOI), monthly SOI data were collected from the National Oceanic and Atmospheric Administration (NOAA) website (www.noaa.gov). As it is based on the methodology given by Ropelewski and Jones (1987), the lower index values (negative values) indicate weak to strong El Niño events. The linkage of monsoon rainfall with El Niño is weakening at the national level (Kumar et al. 1999; Shewale and Kumar 2005). In the present investigation, therefore, an attempt has been made to correlate monsoon rainfall and average SOI for the monsoon period.

Apart from this, to estimate the future (up to 2050) drought events and temperature changes, the projected Coordinated Regional Downscaling Experiment (CORDEX) data were acquired from the Indian Institute of Tropical Meteorology (IITM), Pune, for the geographical area demarcated by $16^{\circ} 45^{\prime}-19^{\circ} 25^{\prime} \mathrm{N}$ latitude and $73^{\circ} 45^{\prime}-76^{\circ} 25^{\prime} \mathrm{E}$ longitude (Fig. 2) to cover all the five semiarid basins under study. CORDEX South Asia data include simulations performed by the Swedish Meteorological and Hydrological Institute (SMHI) and from the Rossby Centre regional climate model (RCM) Rossby Center Atmospheric Model version 4 (RCA4), using CMIP5 GCM EC-Earth (Hazeleger et al. 2011; Strandberg et al. 2014). This model is based on the representative concentration pathway 4.5 , which assumes peak greenhouse gas emission around 2040. As the present investigation attempts to highlight expected climatic changes over study areas/basins in the near-term future (up to 2050), the RCA4 climate projection model was selected. The yearly projected mean temperature and monsoon rainfall values for the period between 2015 and 2050 were obtained by averaging all pixel values in the demarcated area for each year. 


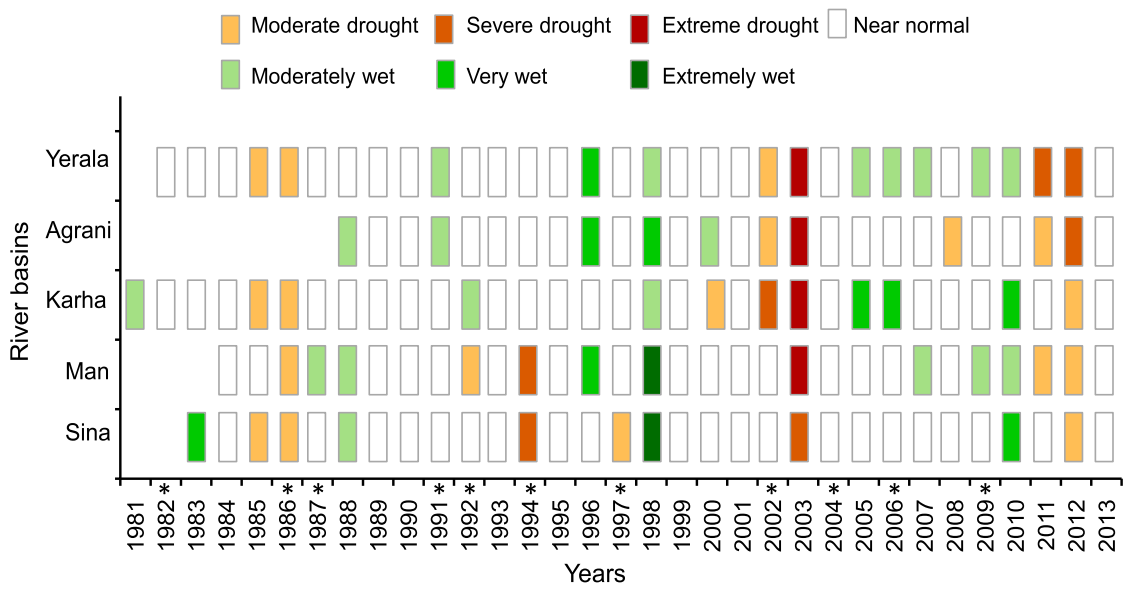

FIG. 3. Basin-wise drought severity classes for the yearly monsoon rainfall. Asterisks (*) denote El Niño events (from weak to very strong).

\section{b. Standardized precipitation index}

The SPI, developed by McKee et al. (1993), is an index used worldwide to identify meteorological drought conditions by their intensity, as it requires only precipitation data as an input. It is the standardized deviation of rainfall from its long-term mean. Generally, the precipitation data are not normally distributed. Therefore, the application of appropriate probability distribution is the prerequisite to transform the data. Generally, gamma or Pearson type III probability distributions are applied for this transformation (McKee et al. 1993; Heim 2002). Before deciding the appropriate probability distribution for the basin-wise rainfall data, the goodness of fit for the available distributions was tested in the MINITAB and Easy Fit software. In the present study, the gamma distribution was used, as it was observed to be most suitable for all the rainfall data series. The SPI can be calculated for 1-, 3-, 6-, 9-, 12- and 24-month time scales. In the case of the present study area, the monsoon period is observed for five months (June-October). As a result, the agricultural practices are normally active for a short duration (during the monsoon and postmonsoon periods). Therefore, only the monsoon period was considered for the calculation of the SPI. The methodology explained by Naresh Kumar et al. (2009) was adopted to calculate the SPI.

The SPI is based on the $Z$-score methodology. Therefore, to relate the SPI with the agricultural productivity and cropped area, two additional indices are proposed: the standardized crop-area index (SCAI) and standardized crop-productivity index (SCPI) to evaluate years with low and high-cropped area and productivity. The indices were computed using the following formulas:

$$
\mathrm{SCAI}=\left(A_{j}-A_{m}\right) / \sigma,
$$

where $A_{j}$ is the area under a particular crop at the $j$ th observation, $A_{m}$ is its long-term mean, and $\sigma$ is its standard deviation. The SCAI is negative when the area under a crop declines. The formula for SCPI is

$$
\mathrm{SCPI}=\left(P_{j}-P_{m}\right) / \sigma
$$

where $P_{j}$ is the productivity of a crop at the $j$ th observation, $P_{m}$ is its long-term mean, and $\sigma$ is its standard deviation. The SCPI is negative when the crop productivity declines.

\section{c. Drought frequency analysis}

As the SPI is based on the concept of probability, return periods of droughts of variable intensity (moderate to extreme) were estimated by using lessthan probabilities. Therefore, the same distribution and its parameters were employed to estimate the cumulative probabilities. Based on these probability values, the return periods were calculated. The reciprocal of probability is considered as return period (Muthreja 1986; Shaw 1994). Statistically, the return period should not be estimated for the period of more than 2 times the empirical (observed) dataset (Muthreja 1986). In the present study, the rainfall data for the last three decades were considered. Therefore, the estimation of return period up to 50 years (SPI $=-2.05)$ was considered. In the SPI methodology, drought is implied when the index value falls below -1.0 . Hence, the return period of such drought (SPI $=-1.0)$ is termed as the return period of drought with minimum intensity. To present basinwise drought frequencies, the estimated return periods were plotted against the corresponding rainfall values. From these interpolated series, the basin-wise rainfall amounts during the droughts of the return 

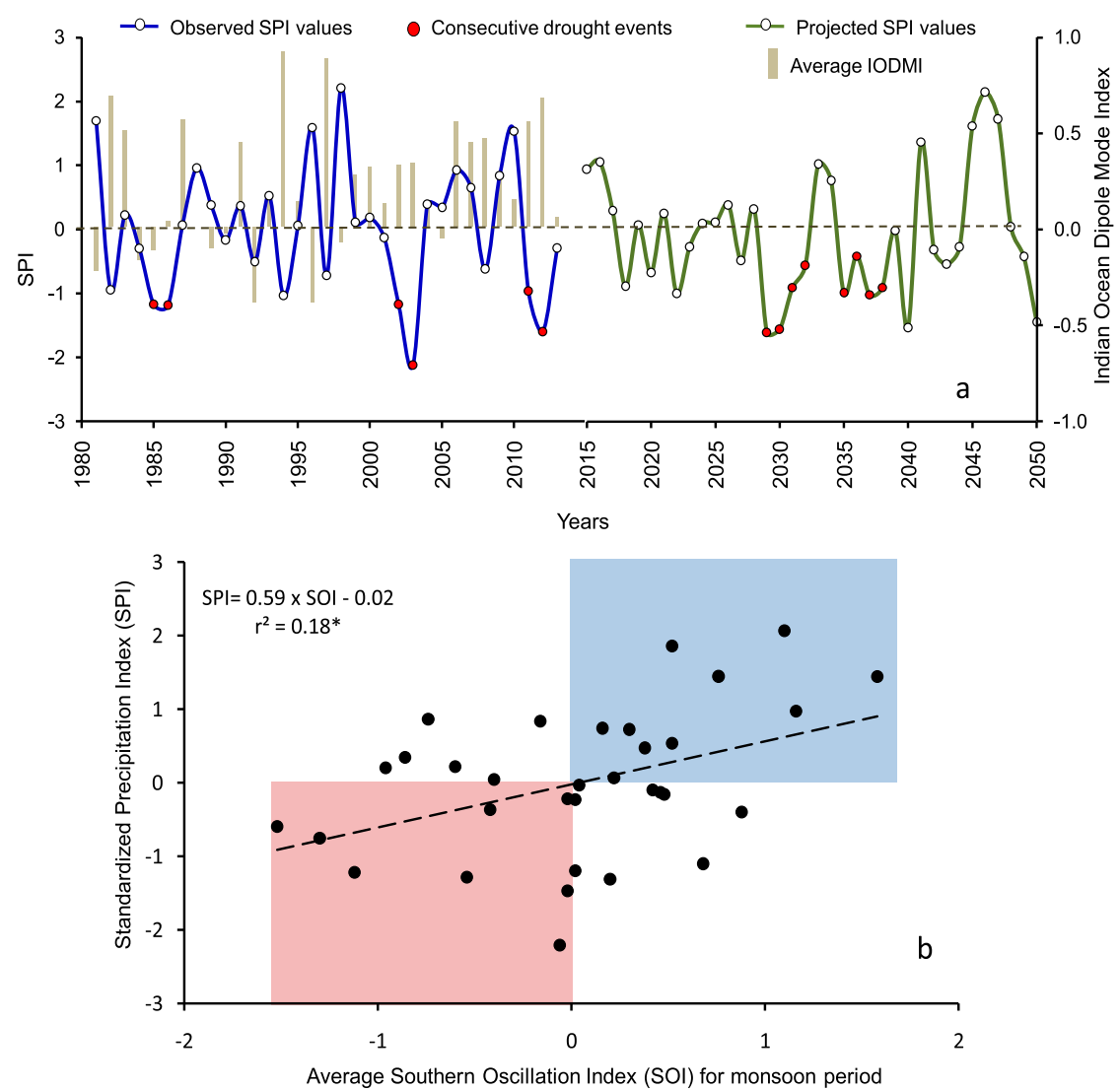

FIG. 4. (a) Time series plot of observed and projected average SPI for five basins. IODMI = Indian Ocean Dipole Mode Index (average for monsoon period). Rainfall data for the year 2014 were not available. (b) Linear relationship between SPI (average for five basins) and SOI for the monsoon period. Dots in the blue and red boxes represent above average (with positive SOI) and below average (with negative SOI) rainfall years. Asterisks (*) denote significant relationship at the $95 \%$ confidence level.

periods of $6,10,15,25$, and 50 years were derived. To identify the average return periods of moderate (SPI from -1 to -1.49 ), severe (SPI from -1.5 to -2 ), and extreme (SPI $<-2$ ) droughts, the estimated return periods in these categories were averaged.

\section{Results and discussion}

\section{a. Meteorological droughts}

All the study basins exhibit region-wide consistency of SPI during the extremely wet and dry years. It suggests considerable spatial coverage of extreme events in rainfall. The drought events such as 1986, 2003, and 2012 were experienced in all the study basins. As against this, 1998 is the only extremely wet monsoon year, which is widespread. Another wet year is 2010, which was experienced in all the study basins, except in Agrani. The remaining dry, wet, and near-normal years do not display agreement with respect to space and time. Among all the droughts, the intensity (from SPI $<-1.5$ to -2.5 ) and coverage (100\% study area) of the drought of 2003 was at a maximum, as the highest SPI was observed in all the study basins, except in Sina. The 2003 drought event is observed in the Sina basin with moderate to severe intensity. Interestingly, the 2002 drought event was observed in all the basins except Sina and Man; contradictorily, the drought of 1994 was observed only in the Sina and Man basins. This drought phenomenon is mainly observed in the Sina and Man basins. The years 1985 and 1986 are also identified as the deficient years over the Sina, Karha, and Yerala basins. However, among all the study basins, the Man basin experienced this drought phenomenon only for one year (1986) (Fig. 3). During the drought of 2012, the Yerala and Agrani basins were severely affected (with SPI $<-1.5$ ) whereas the other basins experienced moderate water scarcity. These spatial anomalies are probably governed by the uneven spatial distribution of monsoon rainfall.

Based on the average monsoon rainfall over the study basins, Fig. 4a exhibits a broad picture of drought events 


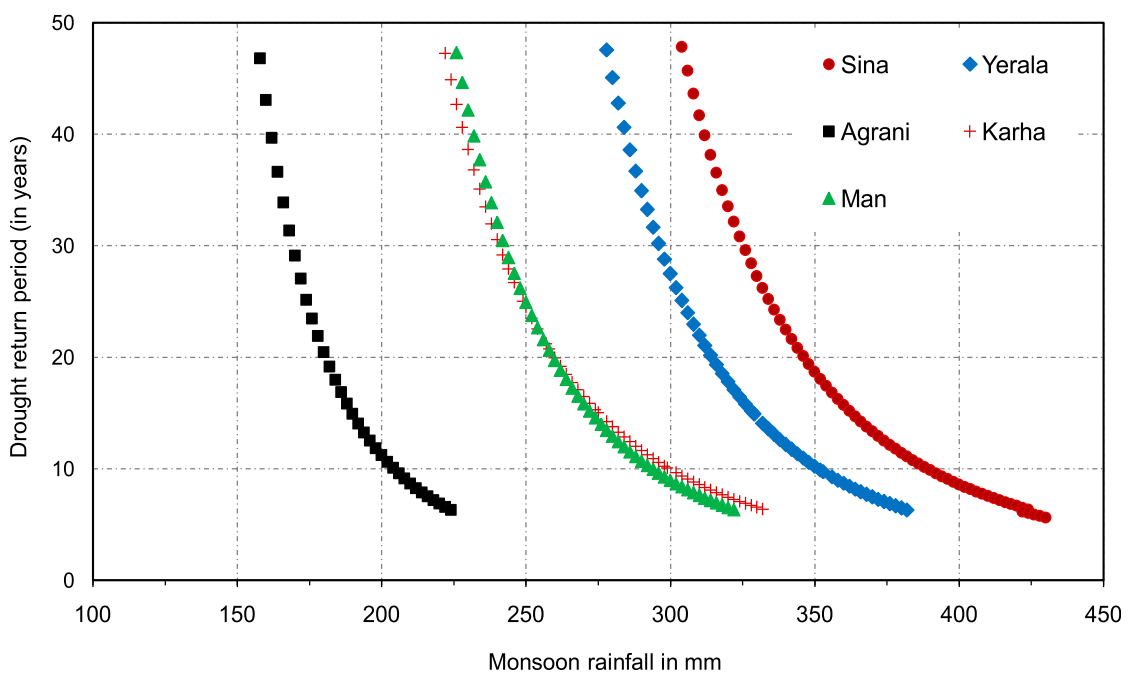

FIG. 5. Basin-wise monsoon rainfall during the droughts of variable return periods.

over the entire study area (average SPI classes for five basins). During the gauge period (1981-2013), three major and regionwide drought events can be noticed (Figs. 3 and 4a) in 1985/86, 2002/03, and 2011/12. These droughts were experienced for two consecutive years, where the second drought year is observed with additional water scarcity. The 1985/86 drought was one of a regionwide drought and was experienced over the study area (selected five basins) and over all the four subdivisions of Maharashtra (Sinha Ray and Shewale 2001) as well. Figure 4a shows the lowest SPI over the study area in the year 2003, as it was the worst drought recorded after 1972 (in terms of coverage) and has adversely affected the land use and land cover in the Krishna basin (including the present study area) (Messina 2013). Similarly, the drought condition in 2012 (with SPI $<-1.5$ ) severely affected the agrarian economy in the rain shadow zone of Maharashtra (Udmale et al. 2014), as it has larger coverage over the study area (Fig. 3). The study carried out by Purandare (2013) has reported that the intensive irrigation for sugarcane cultivation has intensified the 2012 drought. Apart from this, based on the projected monsoon rainfall data, an attempt has been made to estimate the future drought events (Fig. 4a). The severe and consecutive meteorological drought events (consecutively for four years) are expected to occur between 2029 and 2032 and between 2035 and 2038 . It is pertinent to mention here that the annual mean temperature over the semiarid region of Maharashtra has increased (by $0.16^{\circ} \mathrm{C}$ decade $^{-1}$ ) during the last four decades and resulted in increase of potential evapotranspiration (Todmal et al. 2018). The projected annual mean temperature data used in the present investigation indicate rise in temperature by $1.02^{\circ} \mathrm{C}$ up to 2050 , which will notably be amplified after 2030. The study conducted by the World Bank (2008) corroborates the same fact. It suggests that under the climate change scenario, future drought events over the semiarid region of Maharashtra will very likely be aggravated due to the warming condition.

During the recent decades, the connection between Indian monsoon rainfall and $\mathrm{El} \mathrm{Niño} \mathrm{has} \mathrm{become}$ weaker (Kumar et al. 1999; Shewale and Kumar 2005). The monsoon rainfall over the study basins showed a significant relationship with the SOI (average for the monsoon months). The events with negative SOI during June to October retard the monsoon in the study area (five basins). The comparable results obtained by Todmal and Kale (2016) corroborate the same fact. However, there is weak linkage between occurrences of droughts and El Niño events. During the gauge period, although about $60 \%$ of the negative SPI years were associated with negative SOI (Fig. 4b), only two droughts (1986 and 1994) occurred during El Niño years. It can also be noticed that El Niño was active in 2002 and 2004; however, the most extreme drought of 2003 was not associated with El Niño. Similarly, another regionwide drought of 2012 was also not associated with El Niño. It is observed that the occurrence of the Indian Ocean dipole (IOD) is the cause for weakening of the relationship between the Indian summer monsoon and Southern Oscillation index (Saji et al. 1999; Webster et al. 1999). The significant relationship between SPI and IOD obtained for the present study area suggest a partial influence of IOD on the monsoon rainfall over the semiarid region of Maharashtra. The positive IOD during the El Niño 
TABLE 1. Average drought return periods for the study region. The listed drought events have occurred at least in one or more basins. The frequencies of moderate, severe, and extreme drought events are averaged for the study area. The droughts with severe intensity are observed with moderate and extreme intensity in some basins. The drought of 1994 was observed with extreme and severe intensity in the Sina and other basins, respectively.

\begin{tabular}{llcll}
\hline \hline \multicolumn{1}{c}{ SPI } & \multicolumn{1}{c}{ Category } & $\begin{array}{c}\text { No. of times in } \\
100 \text { years }\end{array}$ & $\begin{array}{c}\text { Frequency of } \\
\text { drought event }\end{array}$ & \multicolumn{1}{c}{ Years of drought events recorded } \\
\hline-1.00 to -1.49 & Moderate drought & 10 & 1 in 10 years & $1985,1986,1992,1997,2000,2002,2008,2011$, and 2012 \\
-1.5 to -1.99 & Severe drought & 4 & 1 in 28 years & $1994,2002,2003,2011$, and 2012 \\
$\leq-2.0$ & Extreme drought & 2 & 1 in 50 years & 2003 and 1994 \\
\hline
\end{tabular}

year reduces the effect of El Niño over India to some extent (Ashok et al. 2004). Under such circumstances, it can be stated that the intensity and the coverage of 1994 and 1997 droughts over the study area (Figs. 3 and $4 \mathrm{a}$ ) were controlled by the positive IOD, as the Indian Ocean dipole mode index (average for monsoon months) values were observed at 0.91 and 0.88 respectively in these two years (Fig. 4a).

\section{b. Estimation of monsoon rainfall vis-à-vis drought return periods}

Based on the return period obtained for the empirical rainfall data, the interpolated values of the variable return periods with corresponding rainfall are plotted in Fig. 5. As the return periods of drought are calculated by using the SPI methodology, years with SPI values less than -1.0 are treated as drought years. Therefore, in each basin, the drought of least intensity (SPI -1.0) occurs once in six years, albeit there are basin-wise variations in the monsoon rainfall. In spite of being in the same climatic region, interbasin variations in the monsoon rainfall during the droughts of same return period can be noticed (Fig. 5). Among all the study basins, the Sina basin reveals comparatively higher rainfall amounts $(300-425 \mathrm{~mm})$ during the drought of variable return periods between 6 and 50 years, followed by the Yerala basin. In the Agrani basin, moderate to extreme droughts are observed with lower monsoon rainfall between 150 and $225 \mathrm{~mm}$. By and large, the Karha and Man basins broadly display similar amount of monsoon rainfall during the drought events (Fig. 5). These basins are experiencing the once-in-six-year drought event (when the SPI $=-1$ ) with the monsoon rainfall amount of $\sim 320 \mathrm{~mm}$. Among the study basins, the Agrani basin reveals the highest deficiency of rainfall during the selected drought events of variable return periods. It is pertinent to mention here that the Karha, Agrani, and Man basins mostly fall in the chronic to severe meteorological drought-prone zone identified by Khambete and Biswas (1984). Additionally, the study conducted by Dikshit (1983) has found that these rivers drain the area which is characterized by the highest water deficiency
$(900-1100 \mathrm{~mm})$ in the state. There are three pockets in India (observed in Gujarat-Punjab, Maharashtra, and Karnataka States) with lowest crop potential (Biswas and Nayar 1984). One of these pockets (in Maharashtra) is the area drained by the Karha, Man, and Agrani Rivers where drought disaster with consecutive 10 dry weeks has the highest frequency (once in three years) (Khambete and Biswas 1984; Deosthali 2002). Such frequent water scarcity events adversely affect the agricultural productivity, particularly during the rabi (postmonsoon) season (Khambete and Biswas 1984).

The drought events experienced over the study area are also classified in drought categories according to their intensity (SPI value). It can be observed that the drought frequency is inversely associated with the drought intensity. In other words, the extreme drought events (SPI $\leq-2.0)$ occur very rarely and vice versa. In the study area, extreme droughts were experienced in 1994 and 2003. However, in the Man and Sina basins (about $70 \%$ of the study area), these two droughts were observed with relatively less intensity and hence were categorized as severe droughts, which occur once in 28 years. Among these two drought events, the drought of 2003 was the worst experienced by the study area after the 1972 drought conditions (Todmal 2016). Interestingly, these two severe drought events (1972 and 2003) have an interval of about 30 years, which is almost comparable with the drought frequency results (Table 1) obtained in the present study. It supports the estimation of extreme drought conditions in the early 2030s (Fig. 4a), which are expected to occur with intervals of $\sim 30$ years from the 2003 drought. The droughts of 2011 and 2012 were observed with moderate to severe intensity over the study basins. The moderate drought event is experienced once in a decade. As these droughts are comparatively less intense, they may occur consecutively for more than two years (e.g., the droughts of 1985/86 and 2011/12). It can be noticed that majority of the droughts from this category have occurred after 2000 (Table 1). Although marginally below-normal rainfall or mild dryness (SPI between 0 and -0.99 ) is not treated as a 


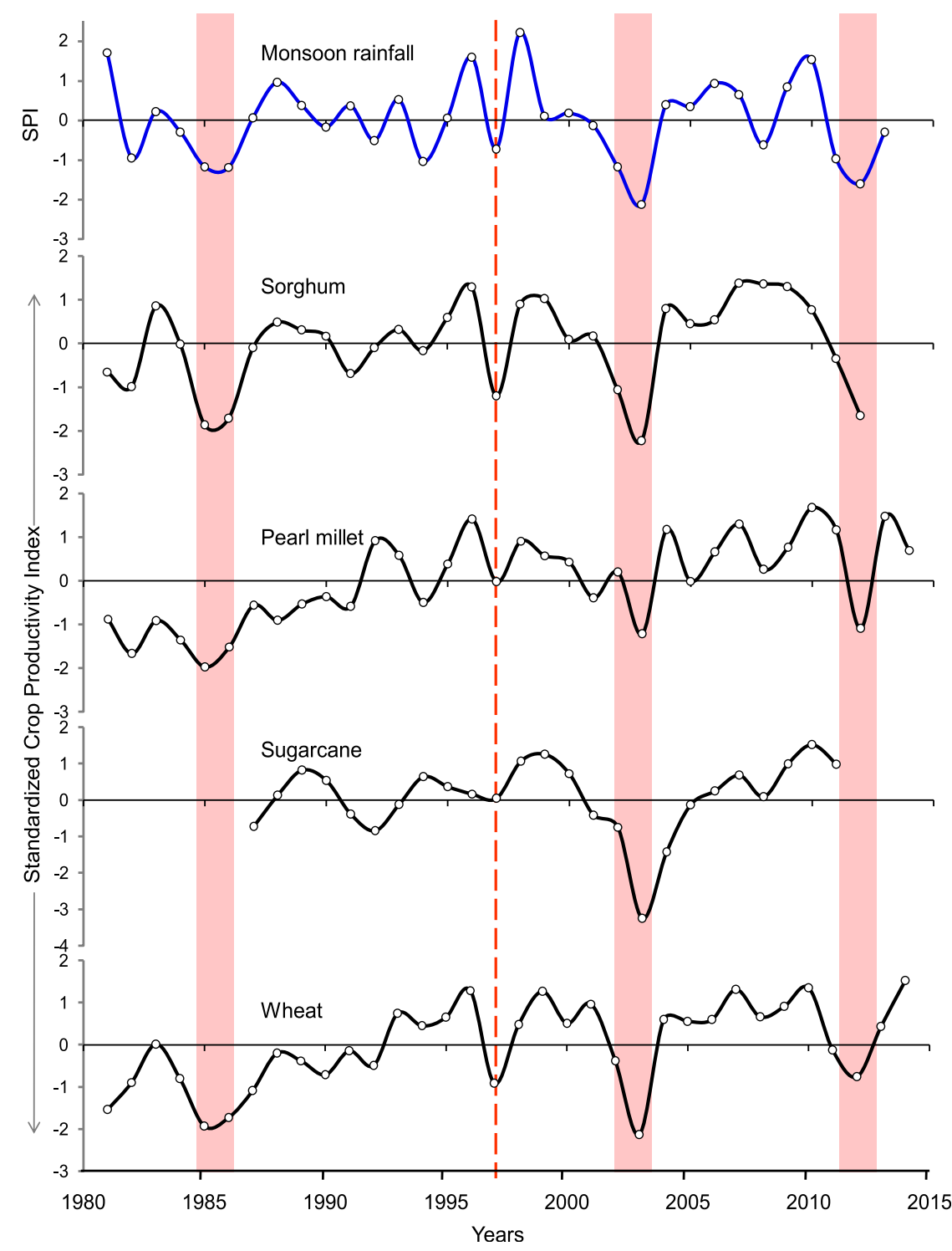

FIG. 6. Temporal variations in SPI and SCPI of major crops for all the study basins. Pink bands represent regionwide severe drought years. The dashed red line shows the severe drought of 1997. Sugarcane and sorghum productivity data were missing for some years.

drought event, it can potentially exacerbate the drought condition if it occurs successively after severe drought. In spite of less intensity, these events probably cause serious socioeconomic damages to a large extent due to the occurrence once in 3-3.5 years. In the Fifth Assessment Report, the IPCC (2013) has estimated an increase in intensity and frequency of droughts over the semiarid regions of South Asia (including the present study area). From Table 1 it is apparent that the frequency of droughts has increased over the study area during the last two decades, perhaps partly due to human-induced climate change. Similar inferences regarding increased frequency of droughts at the all-India level were drawn by Gore et al. (2010).

\section{c. SPI vis-à-vis SCPI and SCAI}

Figure 6 displays the connection between the SCPI and SPI for the average monsoon rainfall over the entire study region. It can be stated that the agricultural productivity is heavily dependent on the monsoon rainfall, as all the selected crops show positive and statistically significant relationship with monsoon rainfall (SPI) (Table 2). Particularly, the rainfed crops such as sorghum and gram $\left(r^{2}=0.51\right.$ and 0.41 , respectively) reveal comparatively good agreement with SPI. As mentioned 
TABLE 2. Coefficient of correlation $\left(r^{2}\right)$ between agricultural drought indices and SPI for the entire study region. Asterisks $(*)$ denote a statistically significant relationship at the $95 \%$ confidence level.

\begin{tabular}{lcccccc}
\hline \hline & \multicolumn{2}{c}{ Rainfed crops } & & \multicolumn{2}{c}{ Irrigated crops } \\
\cline { 2 - 5 } \cline { 3 - 6 } & Sorghum & Pearl millet & Gram & Pigeon pea & Sugarcane & Wheat \\
\hline SCPI & $0.50^{*}$ & $0.23^{*}$ & $0.41^{*}$ & $0.24^{*}$ & $0.29^{*}$ & $0.29^{*}$ \\
SCAI & 0.008 & 0.11 & 0.004 & 0.05 & 0.08 & $0.25^{*}$ \\
\hline
\end{tabular}

earlier, the study basins experienced severe and regionwide droughts in 1985/86, 2002/03, and 2012. Being rainfed crops, the productivity of sorghum, pearl millet, and gram crops was affected to a greater extent during these drought years (Fig. 6). Exceptionally, SCPI values for all the selected crops other than sorghum are near normal in the drought of 2002 (SPI $=-1.17)$. Among the high water-requiring crops, the productivity of wheat exhibits a notable decline during the drought years, as it requires higher amount of water (than millet). This can be observed during the regionwide droughts in 1986, 2002/03, and 2012 (Fig. 6), when almost all the selected

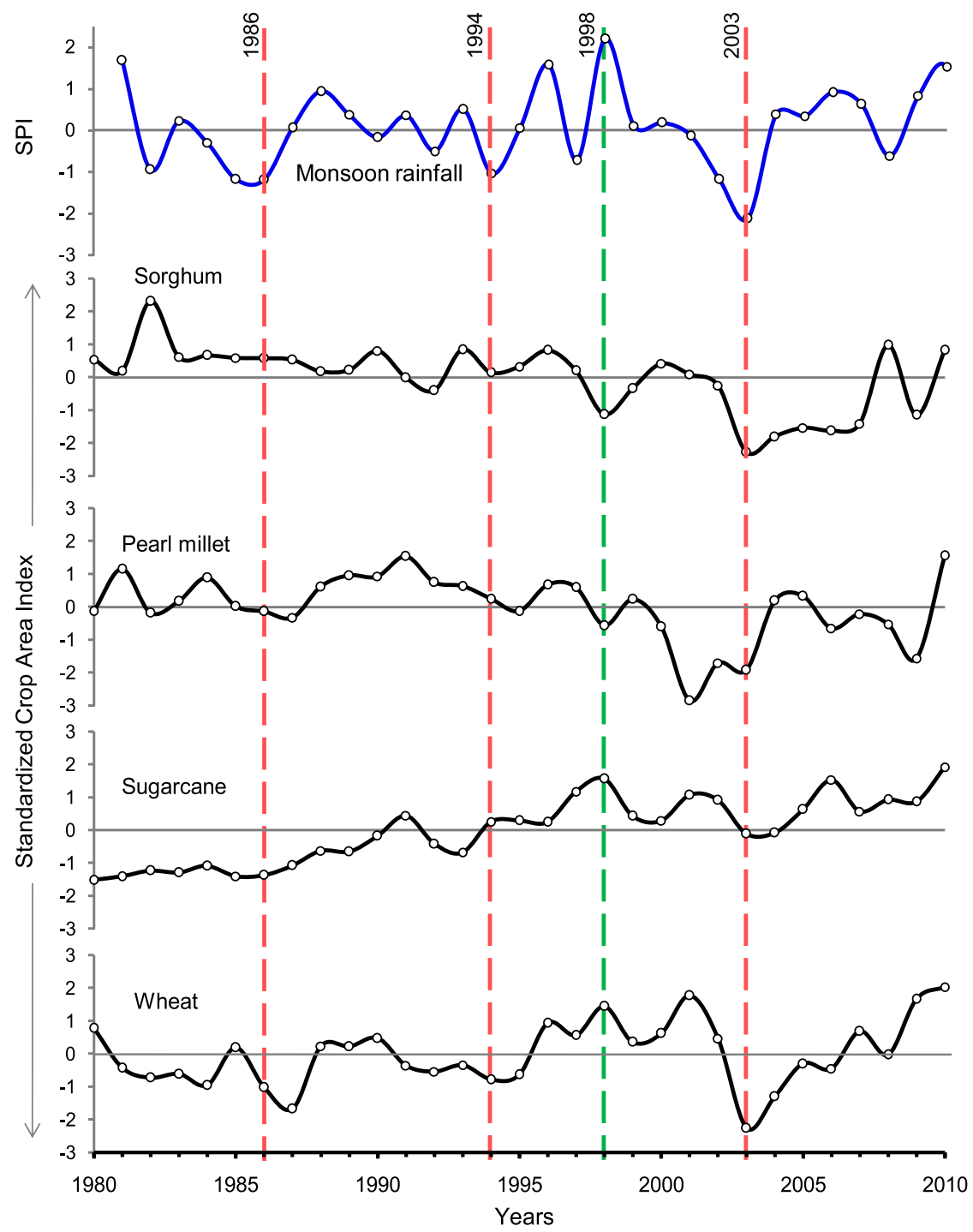

FIG. 7. Annual variations in SPI and SCAI of major crops for the study area. The dashed red lines represent severe to extreme meteorological drought years. The wettest year in the record (1998) is represented by a dashed green line. 
talukas registered below-average yield of wheat. Similarly, the moderate drought of 1997 resulted in the failure of wheat crop to a considerable extent. The worst droughts (with minimum SPI) observed over the study area are in 2003 followed by 2012 and 1986. Among them, the drought of 2003 affects the productivity of rainfed crops and irrigated crops as well. During the last three decades, the extreme drought condition in 2003 resulted in a maximum decline in the productivity of sorghum, sugarcane, and wheat (SCPI $=-2.32,-3.26$, and -2.13 , respectively). As compared to them, pearl millet, gram, and pigeon pea $(\mathrm{SCPI}=-1.32,-1.83$, and -0.52 , respectively $)$ are the less affected crops in 2003. Although sugarcane is irrigated through surface water resources, perhaps due to acute rainfall deficiency for two consecutive years, the maximum decline in sugarcane productivity (SCPI $=-3.26$ ) was registered in 2003 (Fig. 6).

Figure 7 show the temporal fluctuations based on SCAI values for the major crops in the study area. It is evident that lower intensity meteorological droughts (mild to moderate) do not seem to have any noteworthy impact on the crop hectarage. The insignificant relationships between SCAI and SPI for all the selected crops (except wheat) corroborate the same fact (Table 2). The majority of the selected crops are raindependent; these are sown during the early part of the monsoon season, irrespective of the performance of the monsoon during the following months. Therefore, even during the below-normal monsoon year, the area under rainfed crops, as per the government records, is broadly comparable with the cropped area during the normal or wet monsoon year. Perhaps due to this reason, the impact of severe droughts in the 1980s and 1990s is not evident for sorghum, which is a rainfed crop and covers the maximum area in the basins. It is only the severe and extreme meteorological droughts that have a negative impact on the hectarage of rainfed crops (Fig. 7). Almost all the crops exhibit below-average hectarage in 2003, which was an extreme meteorological drought year, preceded by a moderate to severe hydrometeorological drought year (2002). The impact is particularly observed in the case of sorghum, pearl millet, gram, pigeon pea, maize, and wheat crops. Even the area under sugarcane had declined (Fig. 7), which reflects a reduction in the surface and subsurface water available for irrigation. The 2003 meteorological drought, therefore, could also be broadly classified as an agricultural drought year. It is important to mention here that the regionwide drought of 2003 and the flood disaster in 2005 together have consumed more than INR 175 billion, which is more than state's planned budget (INR 150 billion)

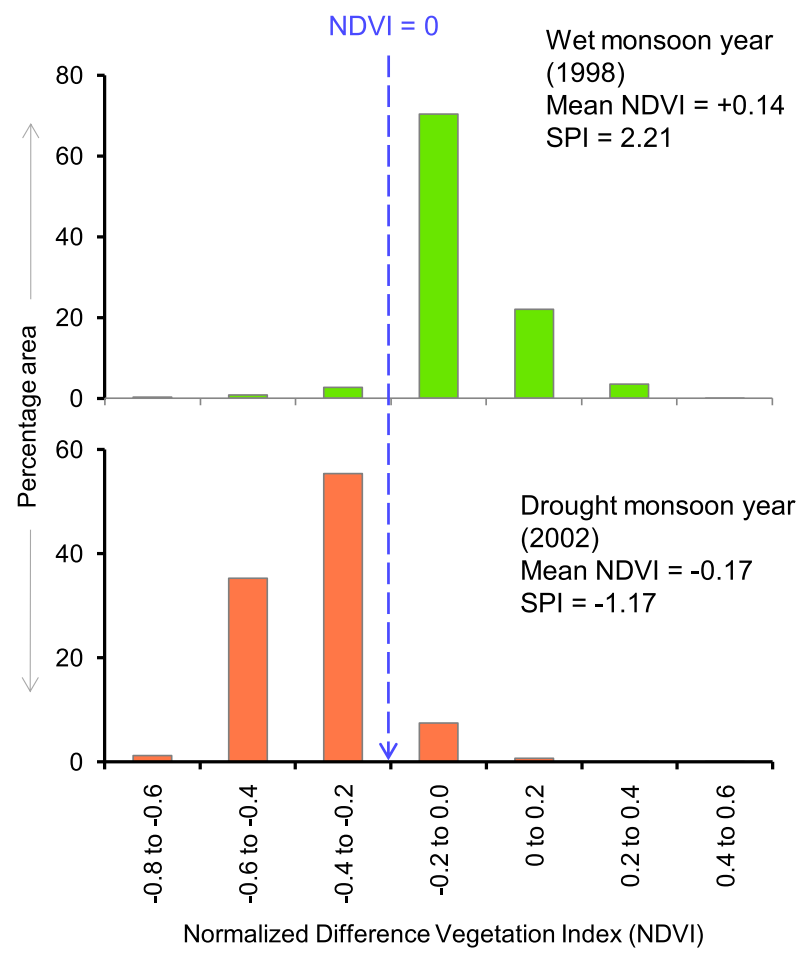

FIG. 8. Histograms showing the percentage area under different NDVI classes in winter (December) for the years 1998 and 2002. The NDVI values were derived from the analysis of Landsat-5 TM data.

for irrigation, agriculture, and rural development for 2002-07 (World Bank 2008; TERI 2012). Similarly, the area under almost all the crops recorded an aboveaverage area in 2010, which was an excess monsoon year (Fig. 7). Surprisingly, the impact of 1998, which was the wettest year on record, is not apparent from the plot. However, there is a remarkable increase in the variability in the crop hectarage after the 1998 wet year.

It is a well-established fact that the cropped area under rainfed crops in Maharashtra is getting replaced by cash crops/high water-requiring crops (Kalamkar 2011; Todmal and Kale 2016). In the present investigation, same fact is apparent. Broadly, the belowaverage area under rainfed crops is observed during the recent years (particularly after 2002). Further, the cropped area under sugarcane, onion, and maize exhibits an increasing trend, particularly after 1987. During the last two decades, the area under sugarcane and onion is very frequently above the long-term mean (Fig. 7). In comparison, the rainfed crops show a considerable decline during the first decade of this century (2000-10). Perhaps because of the availbility of surface water irrigation facility, in spite of the increase in drought frequency and intensity the 
cultivation of high water-requiring crops (sugarcane and wheat) is increasing (after 1995) at the cost of rainfed crops (sorghum and pearl millet). The obtained results compare well with the study carried out by Todmal et al. (2018). There was an unusual increase in the area under sorghum crops in 2008. The reasons for that could not be ascertained.

\section{d. Monsoon condition and NDVI}

On account of the limitation in the agricultural data (mentioned in previous section), the variations in the agricultural cropped area do not show good agreement with SPI (Table 2). However, Dodamani et al. (2015) have found a good positive relationship between NDVI and SPI for the upper Krishna basin. Therefore, in order to ascertain the role of monsoon rainfall to determine variations in agricultural cropped area in the study area, freely available satellite images of Landsat-5 TM for the years 1998 and 2002 (SPI values 2.21 and -1.17 , respectively) were analyzed. From Fig. 8 it is evident that the frequency of positive values is higher during the wet year (1998) and the frequency of negative values is higher during the dry year (2002). The frequency plot shifts from right (positive NDVI) to left (negative NDVI) with a decrease in the monsoon rainfall. The positive NDVI values indicate dense or healthy vegetation cover and vice versa (Myneni et al. 1995; Pettorelli et al. 2005). The average NDVI value for the wet monsoon (1998) and drought monsoon years are +0.14 and -0.17 , respectively. Additionally, the result obtained from a Student's $t$ test suggests that the basin-wise NDVI values for the year 2002 are significantly lower than those that are observed in 1998. Thus, it is clear that the area under vegetation cover (and cropped area) significantly drops during the drought years.

\section{Conclusions}

The present investigation has confirmed that the study area has experienced three major region-wide drought events in 1986, 2003, and 2012. During the droughts of severe to extreme intensity, the estimated monsoon precipitation is notably low $(<330 \mathrm{~mm})$; this is the worth considerable finding to manage the water scarcity challenge, particularly in the Agrani and Karha basins. The meteorological droughts over the study area are mainly accountable for the agricultural droughts. Therefore, in order to sustain the agrarian economy through better agricultural yield, drought disaster management authorities should focus on the severe to extreme droughts and the mild droughts too (as they occur more frequently). The role of anthropogenic activities and climate change in the rain shadow zone of Maharashtra need to verify, as the frequency of droughts augmented during the recent years. The significant relationships between SOI and SPI and between SOI and IOD (dipole mode index) that have emerged from the present investigation can be incorporated to precisely forecast the monsoon as well as droughts over the study area. The future rise in temperature (up to 2050) will not only amplify the meteorological droughts (through augmentation of evaporation rate and agricultural water demand) over the study basins but also adversely affect the agricultural productivity, which may lead to severe socioeconomic damages. Therefore, under the climate change scenario, to cope with the future drought disaster (in the early and late 2030s) in the semiarid region of Maharashtra, it is pertinent to increase the level of water literacy of society; additionally, agronomists and water resources managers must have well-defined strategies.

Acknowledgments. The author would like to thank all the government agencies for supplying the required data for this study. The author also expresses his sincere gratitude to Dr. Vishwas S. Kale for his valuable guidance to carry out the present work. The author is grateful to the anonymous reviewers for their comments and suggestions, which helped in improving this manuscript.

\section{REFERENCES}

Ajai, A., A. S. Arya, P. S. Dhinwa, S. K. Pathan, and K. G. Raj, 2009: Desertification/land degradation status mapping of India. Curr. Sci., 97, 1478-1483, https://www.jstor.org/ stable/24107342.

Ashok, K., Z. Guan, N. H. Saji, and T. Yamagata, 2004: Individual and combined influence of ENSO and the Indian Ocean dipole on the Indian summer monsoon. J. Climate, 17, 3141-3155, https://doi.org/10.1175/1520-0442(2004)017<3141:IACIOE> 2.0.CO;2.

Bhuiyan, C., R. P. Singh, and F. N. Kogan, 2006: Monitoring drought dynamics in the Aravalli region (India) using different indices based on ground and remote sensing data. Int. J. Appl. Earth Obs. Geoinf., 8, 289-302, https://doi.org/ 10.1016/j.jag.2006.03.002.

Biswas, B. C., and P. S. Nayar, 1984: Quantification of drought and crop potential. Mausam, 35, 281-286, http://agris.fao.org/agrissearch/search.do? recordID =US201302051152.

Chowdhury, A., and V. P. Abhyankar, 1984: A Markov chain model for the probability of drought incidence in India. Mausam, 35, 403-405.

Das, H. P., P. A. Kore, and V. N. Jadhav, 2003: An effective method of identification of drought in kharif season. Mausam, 54, 909 916, http://metnet.imd.gov.in/mausamdocs/154412_F.pdf.

Deosthali, V., 2002: Dry farming in Maharashtra. Geography of Maharashtra, J. Diddee et al., Eds, Rawat Publications, 180-196, https://books.google.co.in/books/about/Geography_of_ Maharashtra.html?id=Ey1uAAAAMAAJ\&redir_esc=y. 
Dikshit, J., 1983: Identification of drought-prone areas and prediction of crop expectation in Maharashtra. Geogr. Rev. India, 42, 48-81.

Dodamani, B. M., R. Anoop, and D. R. Mahajan, 2015: Agricultural drought modeling using remote sensing. Int. J. Environ. Sci. Dev., 6, 326-333, https://doi.org/10.7763/IJESD.2015.V6.612.

Gadgil, A. S., 2002: Rainfall characteristics of Maharashtra, Geography of Maharashtra, J. Diddee et al., Eds., Rawat Publications, Jaipur, 89-101, https://books.google.co.in/books/about/Geography_ of_Maharashtra.html?id=Ey1uAAAAMAAJ\&redir_esc $=y$.

Gore, P. G., and K. C. Sinha Ray, 2002: Variability of drought incidence over districts of Maharashtra. Mausam, 53, 533-538. http://metnet.imd.gov.in/mausamdocs/25341.pdf.

__ , T. Prasad, and H. R. Hatwar, 2010: Mapping of drought areas over India, National Climate Center Research Rep. 12/2010, Indian Meteorological Department, Pune, 21 pp., http://www.imdpune.gov.in/Clim_Pred_LRF_New/Reports/ NCCResearchReports/research_report_12.pdf.

Guhathakurta, P., and E. Saji, 2013: Detecting changes in rainfall pattern and seasonality index vis-à-vis increasing water scarcity in Maharashtra. J. Earth Syst. Sci., 122, 639-649, https:// doi.org/10.1007/s12040-013-0294-y.

Gumma, M. K., P. S. Thenkabail, and A. Nelson, 2011: Mapping irrigated areas using MODIS 250 meter time-series data: A study on Krishna River Basin (India). Water, 3, 113-131, https://doi.org/10.3390/w3010113.

Hazeleger, W., and Coauthors, 2012: EC-Earth V2.2: Description and validation of a new seamless Earth system prediction model. Climate Dyn., 39, 2611-2629, https://doi.org/10.1007/ s00382-011-1228-5.

Heim, R. R., 2002: A review of twentieth-century drought indices used in the United States. Bull. Amer. Meteor. Soc., 83, 1149 1165, https://doi.org/10.1175/1520-0477-83.8.1149.

Hisdal, H., and L. M. Tallaksen, 2000: Introduction. Drought Event Definition, H. Hisdal and L. M. Tallaksen, Eds., ARIDE Tech. Rep. 6, 1-2, http://www.droughtmanagement.info/ literature/UNIVERSITYofOSLO_Drought_Event_Definition_ 2000.pdf.

IMD, 2005: Climate of Maharashtra. India Meteorological Department, http://www.imdpune.gov.in/.

IPCC, 2013: Climate Change 2013: The Physical Science Basis. T. F. Stocker et al., Eds., Cambridge University Press, 1535 pp.

Kalamkar, S. S., 2011: Agricultural Growth and Productivity in Maharashtra: Trends and Determinants. Allied Publishers, 218 pp.

Khambete, N. N., and B. C. Biswas, 1984: Application of Markov chain model in determining drought proneness. Mausam, 35, 407-410.

Kumar, K. K., B. Rajagopalan, and M. A. Cane, 1999: On the weakening relationship between the Indian monsoon and ENSO. Science, 284, 2156-2159, https://doi.org/10.1126/ science.284.5423.2156

Maliva, R., and T. Missimer, 2012: Aridity and drought. Arid Lands Water Evaluation and Management, Springer-Verlag, 21-39.

McKee, T. B., N. J. Doesken, and J. Kleist, 1993: The relationship of drought frequency and duration to time scale. Eighth Conf. on Applied Climatology, Anaheim, CA, Amer. Meteor. Soc., http:// www.droughtmanagement.info/literature/AMS_Relationship_ Drought_Frequency_Duration_Time_Scales_1993.pdf.

Messina, A. T., 2013: Mapping drought in the Krishna Basin with remote sensing. Ph.D. thesis, San Diego State University, 51 pp., http://sdsu-dspace.calstate.edu/handle/10211.10/3476.

Mishra, K., and V. P. Singh, 2010: A review of drought concepts. J. Hydrol., 391, 202-216, https://doi.org/10.1016/j.jhydrol.2010.07.012.
Muthreja, K. N., 1986: Applied Hydrology. Tata McGraw Hill, 959 pp. Myneni, R. B., F. G. Hall, P. J. Sellers, and A. L. Marshak, 1995: The interpretation of spectral vegetation indexes. IEEE Trans. Geosci. Remote Sens., 33, 481-486.

Naresh Kumar, M., C. S. Murthy, M. V. R. Sesha Sai, and P. S. Roy, 2009: On the use of Standardized Precipitation Index (SPI) for drought intensity assessment. Meteor. Appl., 16, 381-389, https://doi.org/10.1002/met.136.

Palmer, W. C., 1965: Meteorological drought. Research paper 45, Office of Climatology, U.S. Weather Bureau, 58 pp., https:// www.ncdc.noaa.gov/temp-and-precip/drought/docs/palmer.pdf.

Pandey, R. P., S. K. Mishra, R. Singh, and K. S. Ramasastri, 2008: Streamflow drought severity analysis of Betwa river system (India). Water Resour. Manage., 22, 1127-1141, https://doi.org/ 10.1007/s11269-007-9216-6.

Pettorelli, N., J. O. Vik, A. Mysterud, J. M. Gaillard, C. J. Tucker, and N. C. Stenseth, 2005: Using the satellite-derived NDVI to assess ecological response to environment change. Trends Ecol. Evolut., 20, 503-510, https://www.sciencedirect.com/ science/article/pii/S016953470500162X.

Purandare, P., 2013: Water governance and droughts in Marathwada. Econ. Polit. Wkly., 48, 18-21, http://www.indiawaterportal.org/ sites/indiawaterportal.org/files/water_governance_and_droughts_ in_marathwada_0.pdf.

Revadekar, J. V., Y. K. Tiwari, and K. R. Kumar, 2012: Impact of climate variability on NDVI over the Indian region during 1981-2010. Int. J. Remote Sens., 33, 7132-7150, https://doi.org/ 10.1080/01431161.2012.697642.

Ropelewski, C. F., and P. D. Jones, 1987: An extension of the Tahiti-Darwin Southern Oscillation Index. Mon. Wea. Rev., 115, 2161-2165, https://doi.org/10.1175/1520-0493(1987)115<2161: AEOTTS $>2.0 . \mathrm{CO} ; 2$.

Saji, N. H., B. N. Goswami, P. N. Vinayachandran, and T. Yamagata, 1999: A dipole mode in the tropical Indian Ocean. Nature, 401, 360-362, https://doi.org/10.1038/43854.

Shaw, E. M., 1994: Hydrology in Practice. Chapman and Hall, 463 pp.

Shewale, M. P., and S. Kumar, 2005: Climatological features of drought incidences in India, Meteorological Monograph (Climatology 21/2005), National Climate Centre, Indian Meteorological Department, $22 \mathrm{pp}$.

Shukla, S., and A. W. Wood, 2008: Use of a standardized runoff index for characterizing hydrologic drought. Geophys. Res. Lett., 35, L02405, https://doi.org/10.1029/2007GL032487.

Sinha Ray, K. C., and M. P. Shewale, 2001: Probability of occurrence of drought in various sub-divisions of India. Mausam, 52, 541-546, http://metnet.imd.gov.in/mausamdocs/ 15237_F.pdf.

Smakhtin, V. U., and D. A. Hughes, 2004: Review, automated estimation and analysis of drought indices in South Asia. Working paper 83 (Drought series paper 1), International Water Management Institute, 24 pp., https://www.preventionweb.net/files/ 1869_VL102136.pdf.

Strandberg, G., and Coauthors, 2014: Regional climate model simulations for Europe at 6 and $0.2 \mathrm{k} \mathrm{BP}$ : Sensitivity to changes in anthropogenic deforestation. Climate Past, 10, 661-680, https://doi.org/10.5194/cp-10-661-2014.

TERI, 2012: Climate change in Maharashtra: A pioneering adaptation strategy. The Energy and Resource Institute, New Delhi, 1 p.

2014: Assessing climate change vulnerability and adaptation strategies for Maharashtra: Maharashtra State Adaptation Action Plan on Climate Change (MSAAPC). The Energy and Resources Institute, New Delhi, 302 pp. 
Todmal, R. S., 2016: Trend analysis of rainfall, streamflow and groundwater levels in the five semi-arid rivers in the droughtprone area of Maharashtra. Ph.D. thesis, S. P. Pune University, 379 pp.

—_ and V. S. Kale, 2016: Monsoon rainfall variability and rainfed agriculture in the water-scarce Karha Basin, western India. Mausam, 67, 927-938, http://metnet.imd.gov.in/mausamdocs/ 56745.pdf.

— M. S. Korade, A. G. Dhorde, and R. B. Zolekar, 2018: Hydrometeorological and agricultural trends in the water-scarce Karha Basins, western India: Current and future scenario. Arab. J. Geosci., 11, 254, https://doi.org/10.1007/s12517-018-3594-3.

Udmale, P. D., Y. Ichikawa, A. S. Kiem, and S. N. Panda, 2014: Drought impacts and adaptation strategies for agriculture and rural livelihood in Maharashtra State of
India. Open Agric. J., 8, 41-47, https://doi.org/10.2174/ 1874331501408010041.

Van Loon, A. F., 2015: Hydrological drought explained. Wiley Interdiscip. Rev.: Water, 2, 359-392, https://doi.org/10.1002/ wat2.1085.

Webster, P. J., A. M. Moore, J. P. Loschnigg, and R. R. Leben, 1999: Coupled ocean-atmosphere dynamics in the Indian Ocean during 1997-1998. Nature, 401, 356-360, https://doi.org/ $10.1038 / 43848$.

World Bank, 2003: India: Promoting agriculture growth in Maharashtra. Main Report South Asia Region, v.1, World Bank Rep. 25415.

2008: Climate change impacts in drought and flood affected areas: Case studies in India. World Bank Rep. 43946-IN, 148 pp., http://www.preventionweb.net/files/12563_WBindia.pdf. 